\title{
The Portrayal of Muslim Women in Western Media. A Content Analysis of the New York Times and The Guardian
}

\author{
Faiswal Kasirye \\ Department of Communication \\ International Islamic University Malaysia \\ Email: Kasirye.faiswal@gmail.com
}

\begin{abstract}
Women in general have been marginalized and represented with all sorts of images in the media. Specifically, when it comes to how muslim women are pictured especially in the western media, there have been different portrayals that researchers have come across during their multitudes of research studies. The present study is another addition to the already available literature on how muslim women are portrayed in the western media by content analyzing the portrayals in the New York times and the Guardian of the United Kingdom. In particular, the study seeks to examine the ways in which Muslim Women are portrayed in the New York Times and the Guardian's news coverage as well as determining the frames that the two news organizations use in portraying Muslim women in coverage of their news stories regarding their affairs. The study adopted a qualitative content analysis and uses the framing theory to guide the discovery of the findings. 49 stories portraying muslim women in the different ways were discovered after perusing through the two online news organizations. The findings of the study indicate that muslim women in the two sampled news media are portrayed as terrorists specifically because of their dress code where on several occasions the news organizations refer to them as Al-Qaida's and extremists in the way they practice their religion. Therefore, the major portrayal of muslim women lies on the negative aspects that are reported in the organization's media stories. In addition, among the dominant themes in the two news media regarding the way the frame their stories while reporting on muslim women include being financially oppressed, terrorists, extremists, un educated, house wives and sexual objects for men. In the end, framing theory is also supported in the study.
\end{abstract}

Keywords: Content analysis, framing theory, Guardian, muslim women portrayal, New York Times, terrorists, 


\section{INTRODUCTION}

The perceptions of the public towards muslim women are generally always different especially when it comes to most of the western countries. Most of them think that every woman who comes out in public with an islamic veil (Hijab) has some sort of link to terrorism or muslim extremists which often drives the entire discussion to islamophobia. The role of the media as we know it is to disseminate information to the public by way of creating awareness on the different issues affecting communities. However, when it comes to how it represents muslims and women in particular, the pens tend to always change colour, and every media platform finds a befitting way and terms on how to define muslims but women in particular.

There are so many questions that still exist and linger in people's minds especially on issues regarding how the western media portray muslims and muslim women in particular. Panagopoulos, (2006) in his study reveal that, the rate at which muslims adapt to the western values which include acceptance, civility and tolerance is likely to remain negative because of how the muslims are mainly represented in the media in the western countries like the United Kingdom.

It should also be noted that since the early 1970s, media coverage of muslims and their events has been evolving especially in the western perspective. While its increased coverage came with some advantages, the disadvantages put the entire religion of Islam at risk especially when the media start to portray muslim women as terrorism mere because of their dress code or the way they present themselves in the societies where they live (Terman, 2017). Women have also been given a somewhat special attention in terms of coverage for their own commercial gains.

The language used in the media while covering muslims women related activities is very important in understanding how they refer to them in their different stories. The media in the bid to construct an appealing headline on a story tend to craft catchy headlines to get the public eye. However, while doing that, hey tend to appear misleading the public on several topics like that of how they craft issues relating to women in the islamic perspective (Ciftci 2012).

On representing a subject in news coverage whether positively or negatively, Hart and Hassenchal, (2005) argue that, metaphors in news coverage can well be utilized as weapons in crafting issues to dehumanize a person in order to be supported by the public in doing so. This can however happen either negatively or positively regardless of what news media is engaging in the said 
practice. This issue can be seen now days in the media when they want to portray muslims as such, they will just initiate a press coverage of a particular subject relating to muslims, and they simply make it appear as fact, much as it might not be as such. The most predominantly used metaphor relating to muslim women in the western media in general is that of terrorism. This goes far to the extent that if anything close to terrorism act is done by a non-muslim, the media will be cagy in referring to the culprits as terrorists. An example here can be seen on the Killings that happened in Switzerland where a number of muslims were killed in broad day light by a non-muslims with what looked like sponsored acts. The media was quick to just refer to it as mere killings as opposed to if it had been executed by a muslim.

\section{Problem Statement}

Generally, Islam is often represented in the media in contrast to the western practices. Therefore, the western view of the muslims is highly influenced by the many negative images that the western media show to represent how and what muslims are (Terman, 2017). This is seen in this manner because media as the fourth estate charged with the duty of creating awareness to the public on issues that affect them, ought to be neutral and for that matter very objective on all accounts. However, most western media turn stereo typical when it comes to some issues concerning muslims especially women who they know that they are minority and Islam on some occasions prohibits them to speak in public.

On the above account, many people tend to look at women as suicide bombers especially in the west and therefore place some restrictions on them especially regarding the way they dress. There are in fact some countries like the France, Canada and others that have not fully accepted muslim women dress code, to the fact that they have even enacted some laws prohibiting muslim women to come out in public with their muslim veil (hijab) sighting security reasons, and that the reason why women cover themselves is that they are hiding something in their dress code (Zempi, 2014).

In the news York Times specifically, earlier scholars (Greenberg \& Miazhevich, 2012, Mishra, 2007 and Bullock \& Jafri, 2000) intimate that, most of the negative images portraying muslim women in stereo typical ways as terrorists emerged from their news coverages. Later on, several other media agencies adopted the culture and started representing muslim women as such (Qutub, 2017). Back then, most of this negative news about muslim women used to be published in the 
print mainstream media, but currently, with the advent of technology, almost every citizen of the west is a journalist and can express their opinions through the social platforms that have lately swamped the internet.

Therefore, in general, this paper sets out to discover more, how the current western media portray muslim women while singling out the New York Times from the United States and the Uk's the Guardian online news portals. As we shall explore in the literature, Western women in some news stories are portrayed as superior compared to those from the Arab countries or the Middle East who come to the West as migrants or asylum seekers. They often look at them as those coming from the third-world countries as compared to them who hail from first world countries. This divisionism makes women to be referred to in the media as not modern, and therefore not educated and neither are they liberated as the ones from the UK and or US and other western countries. Such divisionism also cartelizes this research to dig deeper in understanding and discovering how such issues relating to muslim women are crafted in the western media. Therefore, this paper will trace the misrepresentations and portrayals of women in the New York Times and the Guardian online news portals.

\section{Research Objectives}

The main objective of this paper is to examine how western media portrays muslim women.

The specific objectives are;

1. To examine how are Muslim Women portrayed in the New York Times and the Guardian's news coverage; and

2. To determine the frames that the New York Times and the Guardian news portals use in portraying Muslim women in the coverage of their news stories.

\section{Research Questions}

1. How are muslim women portrayed in the New York Times and The Guardian's news coverage?

2. What frames do the New York Times and the Guardian news portal use in portraying muslim women in their news coverage? 


\section{Significance of the Study}

There is still a notable lack of research to demonstrate how online news portals like the New York Times and The Guardian portray muslim women issues in their coverage. In line with the above, the findings of this study are expected to contribute to a greater and wider body of knowledge in the theoretical literature and debate relating to media framing and portrayals in journalism under the framework of the Framing theory. Therefore, this paper attempts to fill the gap in research on the representation and portrayal of muslim women in the western media but specifically in the New York Times and the Guardian of the United Kingdom.

Furthermore, it is widely acknowledged by several researchers (Mohanty, 1984; Mishra, 2007 Greenberg \& Miazhevich, 2012) that journalists and media organizations play an important role in framing public conversations around muslim, muslim women and muslims in general. In that vein, the findings from the present study will help guide the public on how the media frames muslim women and what do they base on to do so, and therefore make them aware on how the different conversations regarding muslim women issues are arrived at, and what kind of issues the media consider while publishing the different stories regarding muslims. Additionally, the study will also help the public to scale the discussions in the public but about muslim women in particular.

As the literature spells it out regarding few studies exploring the treatment of muslim women on online news portals in the western media, the findings from the present study that concentrates on the New York Times and the Guardian online news portals as the case studies will help policy makers in understanding how the news they read about muslim women as terrorist is come by. Therefore, the study will provide useful information to policy makers for future policy formulation on news management and also freedom of expression laws and regulations to regulate the way the media treats and frames their news in relation to muslim women whom they treat as minorities in the two countries of the United States and the United Kingdom.

The results from the study will also help journalists and media practitioners in general, in enhancing the way they cover muslim women and how they portray them in their daily news stories. In addition, communication between the muslim women and journalists who cover them could also be enhanced, in order to better understand them and differ from representing them in a negative way because they also have a lot of positive things about them. 
Practically, the study will help journalists particularly those at the New York Times and the Guardian and others in general to adjust their mindset regarding muslim and muslim women in general, and prepare them in covering them with an objective mind especially during situations where they encounter negative statements and news regarding muslim women.

The findings from this research are also expected to contribute to the existing scholarly knowledge in the domain of media portrayals, and will be eminent, specifically for the New York Times and the Guardian online news portals, especially in enhancing their lenses in the way they represent the images of muslim women in their news coverages.

\section{LITERATURE REVIEW}

\section{Framing Theory}

This study applies framing theory as the appropriate theoretical framework. This concept was first advanced by Gregory Bateson in 1972. He defined psychological frames as a "spatial and temporary bounding of a set of interactive message" (Bateson, 1972, p. 197) that operates as a form of meta communication (Hallahan, 2011).

Framing describes the practice of thinking about news items and story content within familiar context. It is related to the agenda-setting tradition but expands by focusing on the core of the issues at hand rather than on some particular topics. The foundation of framing theory is that the media focuses its attention on certain events and people and then places them within meaning (Scheufele \& Dietram, 1999).

Furthermore, the theory suggests that, how issues are presented to the audience called "the frame", influences their choices, and how they eventually process that information. Frames are concepts that work to organize or assemble the meaning of the message. The most common frames often used, are those around the daily news concepts that we see in the media. The theory explains how the media creates frames by introducing news items with predefined and narrow contextualization. They can also be created as shortcuts to link stories to the bigger picture. In the field of social science, framing theory comprises of a huge part of scholarship (Borah, 2011). The earlier studies 
on framing (Goffman, 1974; Entman, 1993; Scheufele, 1999; Matthes, 2009) provided a huge literature on the understanding of framing or media framing.

Entman (1993) points out in his study that, framing involves two processes including selection and salience. He further defined media framing as "to select some aspects of a perceived reality and make them more salient in a communicating text, in such a way as to promote a particular problem definition, causal interpretation, moral evaluation, and/or treatment recommendation" (p. 2).

Today, people are exposed to a diversity of media contents from a variety of sources anywhere anytime in the media landscape (De Vreese \& Neijens, 2016). This sort of news is what shapes their daily life because, once they see a certain news bulletin on television or hear it on a radio station or even read about a catchy headline in the newspapers or in an online platform, they often get interested to know more about a particular subject that is being written about in the news. Their desire to know why a certain news story made headline increases and the more they read about it, the more they become more informed about the issue or else get more intrigued to look for more information regarding the same. It is worthy to note that, the way we react to certain news published in the news media is different depending on what agenda the particular frame fronts for the readers.

Therefore, it is without doubt that the framing theory will be the appropriate theory to guide the current study that deals with exploring how western media portray or represent muslim women in the coverage of their news stories. The study relies on the New York Times and the Guardian of the United Kingdom news portals as the case studies in content analyzing the issues at hand.

\section{Overview of Muslims portrayal in Western Media}

Muslims are portrayed different in the western media platforms depending on the purpose of the frame that is chosen to portray them. The western views look at women as house wives, sex machines and militias on top of being terrorists (Kozlovic, 2007) as compared to men who are views by many as rich billionaires (Abdullah, 2015), suicide bombers (Said, 1995), violent husbands, terrorists, fathers (Greenberg and Miazhevich, 2012) and many more.

In addition, Greenberg and Miazhevich's (2012) while working on a 12 year prolonged project relating to how the media portrays muslims in the New York Times found out that, muslims loved their faith, although in their coverage, the New York times used ethnic phrases like Asian, Arabs, 
Middle eastern immigrants while referring to those who were coming from the Britain. During the 12-year long coverage, the name calling of muslims in general in the New York ties increased to the extent of calling them extremists and radicalisms. The news media also turned their blind eye on freedom of worship and started representing muslim women wearing veils as terrorists especially after the outbreak of the $9 / 11$ in the United states during the years 2001 up to around 2005.

The strong images exhibited in the media today in relation to the muslim woman where they do not want to tolerate the muslim veil attire, did not just happen, it stems very far as a result of the earlier media portrayals of muslims as terrorists (Kabgani, 2013). This makes the present media practitioners in thinking that women always hide bombs in their veils or niqabs especially the fact that they do not remove them off especially while they are in the public. one would actually conclude that, the United States' understanding of muslims as they are portrayed in the media to be terrorists, as one of the reasons why they are laying siege at many middle Eastern as well as Arab countries thinking that they will try to restrict the radicalization of issues in those muslim countries. Therefore, with this mindset as created by the western media, muslims and women in particular need to be sensitized of not feeling inferior for the issues are just framed in a manner that makes them victims of islamophobia.

\section{Muslim Women Portrayal in the Western Media.}

Pew Research Center (2017) in their research report deduced that, majority of western countries do not like muslims as compared to other religious and ethnic groups around the world. most issues as they are framed in their news media relates mostly to the woman and how they veil themselves, and therefore end up concluding that they always hide bombs under their veils and that's why they brand them as bombers and terrorists.

In western media in general, a properly veiled muslim woman is often referred to in their news stories as islamist, member, terrorist (Powell 2011, Dixon \& Williams 2015, Alsultany 2012). The media in the west is still faced with a problem of differentiating who a bomber is or should be and whether a terrorist can be a muslim but at the same time also be a non-muslim. A live example to this is that of New Zealand (Besley \& Peters, 2020) where muslims were killed by a non-muslim gun wielder who came into the mosque and killed almost every one whom he found there and in 
the surrounding area, and the media never branded him as a terrorist as compared to if he had been a muslim.

Several studies in the west have looked at the representation of muslim women in the western media and they conclude, that media in the west published most of its content on muslim women in a negative way (Macdonald, 2006, Saleem \& Ramasubramanian, 2019). The media reports on muslim women generally go beyond to affect the attitudes of the public on the muslim women who often veils themselves while in the public.

Kalkan, Layman, and Uslaner (2009) in their study found the media to be one of the major reasons why the public has a dented imagery of muslim women whenever they see one, because the media influences its subscribers and views as well as listeners to change their attitude depending on the agenda that they have instilled in them basing on the particular frames as they publish them in their news. Therefore, muslim women end up on the bad side of the western people even when they do not get direct contact with them, the conclusions always remain the same.

In the United Kingdom, several studies analyzed reveal that, there are quite many misrepresentations of muslim women. For example, Bullock and Jafri (2000) in their study on how the Guardian in the United Kingdom looks at muslims in their stories found out that, women are constantly seen as oppressed women who are always putting on veils and are constantly victimized by their husbands. This is generally not different from other media outlets like the BBC and others in the United States like the New York Times, Washington Post and many others who look at women as such, and many other negative tendencies. Therefore, scolars like Abu-Lughod (2013) intimate that muslim women need saving and their image repaired because it has been tainted by the media while misrepresenting them.

Whereas most media in the west look at women in that negative manner, the media have not taken cognizant of the fact that what they say does not actually represent the entire muslim Ummah, and that they lack objectivity when it comes to proper representation of a muslim woman image in their news outlets. However, the academia through their many studies have tried to paint somewhat objective picture regarding the coverage of women in the western media. This also prompted this study to dig deeper in understanding how the muslim woman is covered in the two chosen news media which are the New York Times and the Guardian. 


\section{RESEARCH METHODOLOGY}

\section{Research Design}

This study adopted a qualitative content analysis research approach to provide a more vibrant understanding of how the western media portrays muslim women. Curry, Nembhard and Bradley (2009) contend that, qualitative research is built on knowing the relevance and justification that is behind what people do and why they do what they do through understanding their attitudes. The study shall also adopt a purposive sampling technique to make sure that the sampling frame chosen will be relevant to the current study and that it will be able to be representative of the general sample (Tongco, 2007).

The study will employ a qualitative content analysis method to examine how western media taking a case study of the New York Times and the Guardian media, portrays muslim women, as well as finding out the frames that those media often use to portray muslim women as such. Content analysis refers to procedures done for the systematic, replicable analysis of text, videos and or pictures. It involves the classification of parts of a text or video through the application of structured, systematic coding scheme from which conclusions can be drawn about the message content as stated by Paek et al. (2012).

Content analysis is the suitable method for this study because, it is charged with producing results that are replicable and can be generalized to the entire sample. In addition, it is the type of method that can be applied while analyzing written text such as news stories, books, speeches, annual reports and others whether in analog or digital form, in addition to audio visual content (Kripendorf, 2004).

\section{Sampling and Data Collection Procedure}

The study purposely selected and systematically analyzed content from the New York times and the Guardian online media portals that report on muslim women issues.

Articles related to muslim women were selected from the two media's online platforms. Lead paragraphs and headlines will be looked for by keying in words such as "Muslims, muslim women, muslim women and terrorism, terrorism, Islamists, women in Islam" into the media's news website search tools embedded into the website, and only the relevant articles with the key words 
mentioned above will be selected for examination and analysis for the period of one year from 2019 to 2020 .

Articles relating to muslim women including news, columns and opinions, editorials, letters, features and special reports were selected for data gathering. The unit of analysis in this study was a single story where coders were instructed to analyze a randomly selected number of stories published in a certain period of time using a thematic analysis.

\section{Coding}

Since this study is considering open variables because the available variables were not defined at the onset of the study because this is an inductive approach study, a coding scheme will be developed to help in data and frame categorization because "coding is a critical part where the text is broken down into categories, from there the categories can be more closely examined" (Shenk, 2010, p. 51) and themes are generated. Hayes and Krippendorff, (2007) also argue that, while organizing coding schemes for data categorization, coders should retain the original coding scheme to avoid errors and confusion especially since this is in relation to the variables that are open ended.

\section{Data Analysis}

Data gathered from the New York Times and the Guardian media stories were analyzed using content analysis. Firstly, descriptive analyses of means, standard deviations and percentages were considered. In addition, thematic analysis was also applied to extract the meaning from the codes that were generated from the stories relating to the portrayal of muslim women.

\section{FINDINGS AND DISCUSSION}

While examining the New York Times and the Guardian to represent the western perspective in which their news media represent muslim women, I searched for story articles published in the online versions of the two chosen news platforms from sections ranging from the editorial, opinions, news stories, feature stories as well as catchy headlines involving news related to the portrayal of muslim women from March 2019 to 2020. This period was chosen because there has been an ongoing debate on the muslim women dress code (hijab) that has been on going in the west and has been extensively covered by most news media in the west. Additionally, women also 
have no specific time to be targeted as news makers because they are talked about almost all the time in the western news platforms.

The analysis of the stories depended on answering several questions relating to the stories. Among these included, what kind of issues are focused on in particular stories, what do they say about muslim women, are the stories writing facts or fiction, do the stories have muslim voices to show some objectivity, do they address specific issues relating to muslim women do the stories address a specific trend of issues? And many other questions relating to the subject of interest.

The answers to the above questions helped in determining how the news stories portrayed muslim women in their specific media platforms. The articles were analyzed identifying how muslim women are portrayed in the above mentioned stories. Picking from the framing theory as a guiding tool for my analysis, different codes were extracted from the stories and later categorized into themes that represent how muslim women are portrayed in the above news stories.

A quick perusal through the articles from the both news platforms, the New York Times garnered 32 stories and the Guardian was able to generate 17 stories. Among the themes generated after the categorization of the codes included; Financially oppressed, terrorists, extremists, un educated, house wives and sexual objects for men. The analysis included story texts, phrases, descriptions used to portray muslim women, hidden meanings that are not straightened in the article stories, and the sources where the stories were generated from.

\section{The Portrayal of Muslim Women in The Guardian}

Under here, all the frames extracted from the codes generated from the stories apply here, but the most dominant frame in the Guardian news portal is terrorism aside from all the others that include Financially oppressed, un educated, house wives and sexual objects for men.

On terrorism as a theme, several stories do high light the issue as one of the main things that still affect the way they are portrayed. For example, in a (March 1, 2019) opinion titled "long before Shamim Begum, Muslims Women were target” authored by Shelina Janmohamed, it clearly leads with a second headline as the "the isis recruit perfectly embodies the terrorist-victim stereotype that our society still perpetuates". The story starts with a positive imagery of trying to look at the plight of a muslim woman but as you read all the way down, you get to see how it singles out the different aspects a muslim woman is suffering in the UK. This image is directly in conformity with 
Abu-Lughod's (2013) findings who noted that Muslim women in the western countries need saving because their images are overly distorted by the media even when there is no cause for alarm.

In another story (Mark Townsend, march $14^{\text {th }}, 2020$ ), the writer notes in a catchy headline "Met police concedes forcing woman to remove hijab at airport was wrong". The phrasing of the headline does not directly condemn the issue at hand much as a s a writer they have a duty to be objective. The headline tries to bring out the issue as bad in respect of what the police had done but in the introduction of the story, they are not definitive in what they say about the actions of the police to the muslim women whom they were removing veils from. The writer uses words like "could be unlawful" which does not in totality say that the police action was unlawful and a breach of the woman's freedom. This the police were doing using the cover of "counter terrorism schedule 7" which gives them power to stop any one to be checked in suspicion of terrorism activities. The entire story however never made any disclaimer as to the fact that the woman was just another muslim woman and citizen wearing a muslim veil.

In addition, the above story about Aisyah who was undressed at the Heathrow airport for police to take her pictures, she narrates in the story, that she felt embarrassed as if she had been undressed and the fact that the police men insisted that she should remove her veil. For a muslim woman to remove a veil in Islam is like seeing her naked because Islam considers women's entire bodies as nakedness. Therefore, she felt like a sex object for the police men who were insisting on undressing her which she did amidst great pain she notes in the story "For me, it feels the same as if the police had taken a photo of me naked which is in tandem with the findings of Saleem and Ramasubramanian (2019). I felt my dignity had been taken away". This clearly shows that she felt wronged in that manner. The story trended in so many dailies in the United Kingdom because it continues up to the courts of laws.

Several other stories in the guardian also highlight the issue of terrorism among muslim women. Such stories foreample include; (Jamie Grierson, November 3, 2019), (Nazia Parveen, September 2, 2019), (Matilda Boseley, October 29, 2020), (Nosheen Iqbal, September 15, 2019) and many others still single out terrorism as one of the dominant theme that is highlighted in the stories aired by the guardian news portal in this prescribed period. 


\section{The Portrayal of Muslim Women in The New York Times}

Several stories in the New York Times have tried to show muslims and muslim women as disadvantaged and prone to unbalanced reporting $g$ in the news portals news coverage. Firstly, from the themes generated from the codes, terrorism also topples the rest as the main signature that identifies most images of muslim women in the newspapers coverage of muslim women issues.

For example, in a (March 23, 2020) story by Richard Paddock titled 'The 'Niqab Squad' Wants Women to Be Seen Differently" in the story, the headline presupposes that muslim women just want to be treated differently because they wear hijabs. Yet it's not true because they are human being like another but just because when they wear hijabs, the public views them as hiding something in their veils which makes them to start calling them terrorists. I believe that a different headline to this story would have still brought out the news that the media platform wanted to communicate. They clearly brand the women who are wearing niqab as extremists, one of the themes that were extracted from the codes derived from the stories analyzed. Much as the story has positivity in it, the meaning behind most of the statements made indicates otherwise. The terrorism aspect is clearly envisaged in the statements in the story. Dixon \& Williams (2015) in their paper contend that many news media publish stories where they hide some meaning in vague statements that would literally bring out the extremism aspect out of the muslim women. Therefore, the finding here is in conformity with the above researchers.

Awkward headlines in the New York Times describing women with different negative descriptions are what can be received after a quick perusing through the portals website. An example of this is a headline titled " 2 Women Charged with Train Terror Near Canadian Border" authored by Christine Hauser o December 2. The story highlights how two women are responsible for tampering with the train tracks in order to derail them. The major issue here is that they charged the omen of terrorism because of derailing the train a clear manifestation of the government that anything regarding such acts amounts to terrorism.

Therefore, under the theme of terrorism, almost all articles found in the New York Times rests around terrorism although it tries to reflect the other themes, but terrorism being the dominant. 
Terrorism was represented the most by far as compared to the other remaining themes. In fact, if contrasted with the Guardian of the United Kingdom, the situation almost remains the same because they also majorly represent muslim women as terrorists in their news coverage.

From all the codes and themes extracted, terrorism is seen as the central issue. this can further be demonstrated by a story titled "UK woman who joined ISIS in Syria asks High Court to let her return home" by (Elian Peltier, November 24, 2020). The story is referring to Shamim Begum who was a teenager by the time she traveled to Syria without knowing what she was doing but later was charged with terrorism and remains in detention in the UK because her citizenship was also revoked. This is another image portraying muslim women with such an image of terrorism. However, as Islam teaches, not all actions of one person will always tantamount to represent the actions of others. Such actions are what researchers (Kalkan, Layman, \& Uslaner, 2009) hint on in relation to the medias portrayal of women as such. It must be stressed however, that most of the actions taken by the governments in the west depend on the way the media phrases certain issues and places the burden on the government which is in most cases picked up in form of a discussion by the public.

Other images of the muslim women that are portrayed in the New York Times news stories include, muslim women being uneducated, sexual objects for men, house wives and financially unstable. Most of the articles where these themes are derived from include quotes from non-government organizations, government offices, prominent news makers, the police and national security agencies, to which their statements carry a lot of weight in news coverage and ate easily believable by the public that consumes the news that is written by the New York Times.

Other stories may include (Dionne \& Laura Boushnak, March 13, 2020, Henrick Pryser, January 20, 2020, Ainee Ortizz, January 9, 2020) and many others that were analyzed and helped in generating themes from the data extracted from them. 


\section{CONCLUSION}

In conclusion therefore, muslim women face a very big problem of being constructed or portrayed as terrorists and other themes as presented above in the New York Times and the Guardian newspapers. The public severally refer to them as Al-Qaida, terrorists and extremists as well as radical muslims who are just following on the footsteps of their husbands. However, both news media also have some stories that try to soften the muslim woman and muslims at large especially when it comes to the terrorism theme because not all muslims are terrorists and those particular stories try their best to highlight that fact, which is literally ignored by those that write to the contrary. Therefore, from the two papers analyzed, it is clear that the negative news regarding the portrayal of a muslim woman overshadows the positive stories about the same because of the negative and sometimes sexiest and defamatory acts and statements that are published by the newspapers. Of the two, the New York Times is the most impartial one though and comes very hard on the muslim women in their stories. The Guardian tries to avoid stereotyping and name calling muslim women although the statements and the meaning of the stories that they write prove otherwise especially on issues concerning muslim women. It can therefore be summed up that among the 5 themes generated from the codes and data, terrorism is dominant and others follow closely, and that both newspapers used statements referring to muslim women as terrorists. Such portrayals especially to a section of people like women is strongly islamophobia and not encouraged in the newsrooms. The research questions set out at the onset of the study were therefore answered through the analysis of the different frames that were generated from the data. 


\section{REFERENCES}

Abdullah, M. A. S. (2015). Muslims in pre-and post-9/11 contexts. International Journal of Comparative Literature and Translation Studies, 3(3), 52-59.

Abu-Lughod, L. (2013). Do Muslim women need saving? Harvard University Press.

Alsultany, E. (2012). Arabs and Muslims in the Media: Race and Representation after 9/11. NYU Press.

Bateson, G. (1972). Steps to an ecology of mind: Collected essays in anthropology, psychiatry, evolution, and epistemology. University of Chicago Press. Bennett, W. L. (2016). News: The politics of illusion. University of Chicago Press.

Besley, T., \& Peters, M. A. (2020). Terrorism, trauma, tolerance: Bearing witness to white supremacist attack on Muslims in Christchurch, New Zealand.

Borah, P. (2011). Conceptual issues in framing theory: A systematic examination of a decade'sliterature. Journal of communication, 61(2), 246-263.

Bullock, K. H., \& Jafri, G. J. (2000). Media (mis) representations: Muslim women in the Canadian nation. Canadian Woman Studies, 20(2).

Ciftci, S. (2012). Islamophobia and threat perceptions: Explaining anti-Muslim sentiment in the West. Journal of Muslim Minority Affairs, 32(3), 293-309.

Curry, L. A., Nembhard, I. M., \& Bradley, E. H. (2009). Qualitative and mixed methods provide unique contributions to outcomes research. Circulation, 119(10), 1442-1452. https://doi.org/10.1161/CIRCULATIONAHA.107.742775

De Vreese, C. H., \& Neijens, P. (2016). Measuring Media Exposure in a Changing Communications Environment. Communication Methods and Measures, 10(2-3), 6980. https://doi.org/10.1080/19312458.2016.1150441.

Dixon, T. L., \& Williams, C. L. (2015). The changing misrepresentation of race and crime on network and cable news. Journal of Communication, 65(1), 24-39.

Entman, R. M. (1993). Framing: Toward Clarification of a Fractured Paradigm. Journal of Communication, 43(4), 51-58. https://doi.org/10.1111/j.1460-2466.1993.tb01304.

Goffman, E. (1974). Frame Analysis: An Easy on the Organization of Experience. In Harvard University Press.

Greenberg, D., \& Miazhevich, G. (2012). Assimilationism vs. multiculturalism: US identity and media representations of British Muslims over a 12-year span. Communication, Culture \& Critique, 5(1), 75-98.

Hallahan, K. (2011). Political public relations and strategic framing. Political public relations: Principles and applications, 177-213.

Hart, W. B., \& Hassenchal, F. (2005). Culture as persuasion: Metaphor as weapon. Bring'em On: Media and Politics in the Iraq War, 85-100.

Hayes, A. F., \& Krippendorff, K. (2007). Answering the call for a standard reliability measure for coding data. Communication methods and measures, 1(1), 77-89.

Kabgani, S. (2013). The representation of Muslim women in non-Islamic media: A critical discourse analysis study on Guardian. International Journal of Women's Research, 2(1), 57-78.

Kalkan, K. O., Layman, G. C., \& Uslaner, E. M. (2009). "Bands of others”? Attitudes toward Muslims in contemporary American society. The Journal of Politics, 71(3), 847-862. 
Kozlovic, A. K. (2007). Islam, Muslims and Arabs in the Popular Hollywood Cinema. Comparative Islamic Studies, 3(2).

Krippendorff, K. (2004). Reliability in content analysis: Some common misconceptions and recommendations. Human communication research, 30(3), 411-433.

Macdonald, M. (2006). Muslim women and the veil: Problems of image and voice in media representations. Feminist Media Studies, 6(1), 7-23.

Matthes, J. (2009). What's in a frame? A content analysis of media framing studies in the world's leading communication journals, 1990-2005. Journalism and Mass Communication Quarterly, 86(2), 349-367. https://doi.org/10.1177/107769900908600206.

McLeary, P. (2008). Blogging the long war. Columbia Journalism Review, 46(6), 36.

Mishra, P. (2007). Emigration and brain drain: Evidence from the Caribbean. The BE Journal of Economic Analysis \& Policy, 7(1).

Mohanty, C. T. (1984). Under Western eyes: Feminist scholarship and colonial discourses. Boundary 2, 333-358.

Paek, H. J., Reid, L. N., Jeong, H. J., Choi, H., \& Krugman, D. (2012). Five decades of promotion techniques in cigarette advertising: a longitudinal content analysis. Health marketing quarterly, 29(1), 1-17. Oaks: SAGE.

Panagopoulos, C. (2006). The polls-trends: Arab and Muslim Americans and Islam in the aftermath of 9/11. International Journal of Public Opinion Quarterly, 70(4), 608-624.

Pew Research Center (2017) US image suffers as publics around world question Trump's leadership.

Powell, K. A. (2011). Framing Islam: An analysis of US media coverage of terrorism since 9/11. Communication Studies, 62(1), 90-112.

Qutub, A. (2017). The presentation of muslim women in the media. Saving muslim women from their misery.

Said, E. W. (1995). Orientalism: western conceptions of the Orient. 1978. Harmondsworth, Eng.: Penguin, 115 .

Saleem, M., \& Ramasubramanian, S. (2019). Muslim Americans' responses to social identity threats: Effects of media representations and experiences of discrimination. Media Psychology, 22(3), 373-393.

Scheufele, Dietram A. (1999). "Framing as a Theory of Media Effects." Journal of Communication 49 (4): 103-22.

Shenk, C. (2010). Claims and Frames: Newspaper coverage of the Human Papillomavirus Vaccine (Colorado State University). Retrieved from https://mountainscholar.org/bitstream/handle/10217/38368/2010_Spring_Shenk_Caitl in.pdf? sequence $=1 \&$ isAllowed $=y$.

Terman, R. (2017). Islamophobia and media portrayals of Muslim women: A computational text analysis of US news coverage. International Studies Quarterly, 61(3), 489-502.

Tongco, M. D. C. (2007). Purposive sampling as a tool for informant selection. Ethnobotany Research and applications, 5, 147-158.

Zempi, E. C. (2014). Unveiling Islamophobia: The victimisation of veiled Muslim women (Doctoral dissertation, University of Leicester). 